\title{
Perancangan Peralatan Sistem Keamanan Elektronik di SHELTER BTS Secara Real Time Melalui SMS Berbasis MIKROKONTROLLER ATMega16 dan Module GSM
}

\section{Equipment Design Of Electronic Security System In Shelter Real Time Though SMS Based On ATMega16 Microcontroller and GSM Module}

\author{
Muhammad Imam Syarif Siregar ${ }^{1}$, Suwarno $^{2}$, Syarifah Muthia Putri ${ }^{3}$ \\ Program Studi Teknik Elektro, Fakultas Teknik, Universitas Medan Area, Indonesia
}

Diterima: Maret 2019; Disetujui: April 2019; Dipublikasi: April 2019

*Coresponding Email: imamsyarif@gmail.com

\section{Abstrak}

Base Transceiver Station (BTS) merupakan salah satu bagian penting dalam jaringan telekomunikasi. Salah satu bagian dari BTS adalah shelter BTS sebagai tempat perangkat komunikasi disimpan sehingga pemantauan kondisi dan keamanan shelter BTS mutlak dilakukan agar jalur komunikasi dapat berjalan dengan baik. Saat ini, pemantauan kondisi keamanan shelter BTS dilakukan secara manual sehingga diperlukan banyak tenaga dan waktu yang diperlukan untuk memantau sejumlah shelter dimana kondisi sekarang ini perangkat telekomunikasi salah satu objek kriminal bagi sekelompok orang. Hal inilah yang mendorong penelitian untuk merancang bangun sistem keamanan elektronik di shelter BTS melalui SMS agar kondisi shelter BTS secara realtime dapat dimonitor dengan cepat. Perangkat pemantau kondisi keamanan shelter BTS yang dirancang terdiri dari sebuah Mikrokontroler ATMega16 sebagai Pengendali Utama, SIM800L untuk komunikasi, dan LCD sebagai layar tampilan informasi pada shelter BTS. Pengendali utama akan mengirimkan informasi yang terbaca pada shelter BTS ke HP pengguna melalui media SMS menggunakan Modul SIM800. Hasil pengujian secara keseluruhan sistem pada salah satu model shelter BTS yang telah dirancang menunjukkan pemantauan kondisi keamanan shelter BTS secara realtime telah berhasil. Pengendali utama telah dapat mengirimkan informasi kondisi shelter BTS ke HP pengguna dan berhasil ditampilkan pada HP pengguna dengan memberikan peringatan ketika terjadi kondisi yang tidak diharapkan.

Kata Kunci : Mikro Kontroller, Shelter BTS, ATMega16, Module GSM

Abstract
Base Transceiver Station (BTS) is one of the important parts in telecommunications networks. One part of
BTS is the BTS shelter as a place for communication devices to be stored so that monitoring of the
condition and security of BTS shelter is absolutely necessary so that the communication channel can run
well. Currently, monitoring the security conditions of BTS shelters is done manually so that it takes a lot of
energy and time needed to monitor a number of shelters where the current condition of
telecommunications equipment is one of the criminal objects for a group of people. This is what drives
research to design an electronic security system at BTS shelter via SMS so that the condition of BTS shelter
in realtime can be monitored quickly. The monitoring device for BTS shelter security conditions designed
consists of an ATMega16 Microcontroller as the Main Controller, SIMBO0L for communication, and LCD as


an information display on the BTS shelter. The main controller will send the readable information on the BTS shelter to the user's cellphone via SMS using the SIM800 Module. The overall test results of the system on one of the BTS shelter models that have been designed to show monitoring the security conditions of BTS shelters in real time have been successful. The main controller has been able to send information on the condition of the BTS shelter to the user's cellphone and successfully displays it on the user's cell by giving a warning when an unexpected condition occurs.

Keywords : Micro controller, Shelter BTS, ATMega16, Module GSM

How to Cite: Siregar, M, I, S, Suwarno, Putri, M, S. (2019), Perancangan Peralatan Sistem Keamanan Elektronik di SHELTER BTS Secara Real Time Melalui SMS Berbasis Mikrokontroller ATMega16 dan Module GSM(Equipment Design Of Electronic Security System In Shelter Real Time Though SMS Based On ATMegal6 Microcontroller and GSM Module), JESCE (Journal or Electrical and System Control Engineering),2(2):68-79 


\section{PENDAHULUAN}

Keamanan merupakan suatu hal yang sangat penting dan diinginkan oleh perseorangan atau bahkan perusahaan. Tingginya tingkat pencurian dengan pengawasan lingkungan yang minim, membuat orang lain melakukan tindakan yang tidak bertanggung jawab, seperti pencurian terhadap komponenkomponen dari Base Transceiver Station (BTS).

Shelter BTS adalah suatu ruang penyimpanan perangkat BTS yang berukuran sekitar $3 \times 3$ meter persegi. Base station merupakan salah satu perangkat yang sangat berguna dalam sistem jaringan telekomunikasi seluler dan umumnya diletakkan dalam suatu ruangan (Shelter) yang lokasinya tidak jauh dari tower telekomunikasi seluler. Tidak adanya personil keamanan di lokasi shelter BTS dapat menyebabkan terjadinya pencurian. Banyaknya jumlah shelter BTS yang tersebar disutau wilayah jaringan serta jauhnya jarak shelter BTS satu dengan yang lain akan membuat kegiatan pemantauan secara langsung tidaklah efektif dari segi waktu dan tenaga. Dengan menggunakan fasilitas sms dapat dirancang suatu sistem peringatan keamanan pada shelter BTS.
Untuk mengatasi masalah yang ada terkait dengan pemantauan dan keamanan shelter BTS, maka diperlukan suatu sistem peringatan keamanan jarak jauh sehingga dapat mencegah terjadinya kejahatan pencurian pada shelter BTS. Dengan dilengkapinya sistem tersebut akan memudahkan para operator ataupun user yang bertanggaung jawab atas shelter tersebut dalam melakukan pengawasan pada shelter BTS tanpa harus berada di sekitar shelter tersebut. Hal ini mendorong peneliti untuk merancang bangun suatu perangkat keamanan di shelter BTS secara real time melalui komunikasi SMS.

\section{LANDASAN TEORI}

\section{Base Transceiver Station (BTS)}

Base Transceiver Station atau dikenal dengan istilah BTS merupakan bagian penting dalam jaringan telekomunikasi seluler karena BTS inilah yang akan menghubungkan jaringan suatu operator telekomunikasi seluler dengan pelanggannya. BTS terdiri dari tiga bagian utama, yaitu: Tower, Shelter, dan Feeder. Shelter BTS adalah suatu tempat penyimpanan perangkatperangkat telekomunikasi. Shelter BTS berfungsi sebagai media penyimpanan perangkat yang akan terhubung ke 
sebuah pusat perangkat. Pada bagian shelter terdapat berbagai komponen utama dan pendukung seperti combiner, core module, power supply, kipas angin, lampu, dan pintu shelter BTS.

\section{Mikrokontroler ATMega16}

Mikrokontroler adalah sebuah sistem komputer lengkap dalam satu chip. Mikrokontroler lebih dari sekedar sebuah mikroprosesor karena sudah terdapat atau berisikan ROM (Read-Only Memory), RAM (Read-Write Memory), beberapa port masukan maupun keluaran, dan beberapa peripheral seperti pencacah/pewaktu, ADC (Analog to Digital converter), DAC (Digital to Analog converter) dan serial komunikasi. Salah satu mikrokontroler yang banyak digunakan saat ini yaitu mikrokontroler AVR. AVR adalah mikrokontroler RISC (Reduce Instuction Set Compute) 8 bit berdasarkan arsitektur Harvard. Secara umum mikrokontroler $A V R$ dapat dapat dikelompokkan menjadi 3 kelompok, yaitu keluarga AT90Sxx, ATMega dan ATtiny.

Pada dasarnya yang membedakan masing-masing kelas adalah memori, peripheral, dan fiturnya Seperti mikroprosesor pada umumnya, secara internal mikrokontroler ATMega16 terdiri atas unit-unit fungsionalnya Arithmetic and Logical Unit (ALU), himpunan register kerja, register dan dekoder instruksi, dan pewaktu serta komponen kendali lainnya.

Berbeda dengan mikroprosesor, mikrokontroler menyediakan memori dalam chip yang sama dengen prosesornya (in chip)

\section{Memori Data (SRAM)}

Memori data AVR ATMega16 terbagi menjadi 3 bagian, yaitu 32 register umum, 64 buah register $\mathrm{I} / \mathrm{O}$ dan 1 Kbyte SRAM internal. General purpose register menempati alamat data terbawah, yaitu $\$ 00$ sampai $\$ 1 \mathrm{~F}$. Sedangkan memori I/O menempati 64 alamat berikutnya mulai dari \$20 hingga \$5F. Memori I/O merupakan register yang khusus digunakan untuk mengatur fungsi terhadap berbagai fitur mikrokontroler seperti kontrol register, timer/counter, fungsi-fungsi I/O, dan sebagainya. 1024 alamat berikutnya mulai dari $\$ 60$ hingga $\$ 45 \mathrm{~F}$ digunakan untuk SRAM internal

\section{Memori Data EEPROM}

ATMega16 terdiri dari 512 byte memori data EEPROM 8 bit, data dapat ditulis/dibaca dari memori ini, ketika 
catu daya dimatikan, data terakhir yang ditulis pada memori EEPROM masih tersimpan pada memori ini, atau dengan kata lain memori EEPROM bersifat nonvolatile. Alamat EEPROM mulai dari $\$ 000$ sampai $\$ 1 \mathrm{FF}$.

AVR ATMega16 merupakan tipe AVR yang telah dilengkapi dengan 8 saluran ADC internal dengan resolusi 10 bit. Dalam mode operasinya, ADC dapat dikonfigurasi, baik single ended input maupun differential input. Selain itu, ADC ATMega16 memiliki konfigurasi pewaktuan, tegangan referensi, mode operasi, dan kemampuan filter derau (noise) yang amat fleksibel sehingga dapat dengan mudah disesuaikan dengan kebutuhan dari ADC itu sendiri.

\section{Module GSM (Global System Mobile) SIM 800L}

Modul GSM adalah peralatan yang didesain supaya dapat digunakan untuk aplikasi komunikasi dari mesin ke mesin atau dari manusia ke mesin. Modul GSM merupakan peralatan yang digunakan sebagai mesin dalam suatu aplikasi. Dalam aplikasi yang dibuat harus terdapat mikrokontroler yang akan mengirimkan perintah kepada modul GSM berupa AT command melalui RS232 sebagai komponen penghubung (communication links).

Module SIM 800L adalah sebuah modem (Modulator) GSM / GPRS yang bekerja di frekuensi $850-1900 \mathrm{MHz}$ yang memiliki beberapa fitur unggulan diantaranya GPRS multi slot class 12, mendukung kode GPRS CS-1 s/d CS-4, memiliki PIN GPIO (General Purpose Inpot Output) 10 bit, PWM (Pulse Width Mudulation), Radio FM dan masih banyak yang lainnya. Salah satu implementasinya modem SIM800L ini adalah Untuk membuat SMS Controller, sebuah pengendali peralatan elektronik berbasis SMS.

\section{Liquid Crystal Display (LCD) 2x16}

\section{LCD (Liquid Crystal Display)}

merupakan salah satu perangkat display yang umum dipakai dalam sebuah system instrumentasi. Kegunaan LCD banyak sekali dalam perancangan suatu system dengan menggunakan mikrokontroler. LCD (Liquid Crystal Display) dapat berfungsi untuk menampilkan suatu nilai hasil sensor, menampilkan teks, atau menampilkan menu pada aplikasi mikrokontroler. Pada tugas akhir ini, LCD yang digunakan adalah LCD 16 × 2 yang artinya lebar display 2 baris 16 kolom dengan 16 Pin konektor(Agus. 2005). 
Adapun konfigurasi dan deskripsi dari pin-pin LCD antara lain:

VCC (Pin 1): Merupakan sumber tegangan $+5 \mathrm{~V}$

GND OV (Pin 2) : Merupakan sambungan ground

VEE (Pin 3) : Merupakan input tegangan konstras LCD

\section{RS Register select (Pin 4) :}

Merupakan Register pilihan $0=$ Register perintah, $1=$ register data

R/W (Pin 5) : Merupakan read select, $1=$ read, $0=$ write

Enable Clock LCD (Pin 6): Merupakan masukan logika 1 setiap kali pengiriman atau pembacaan data

D0-D7 (Pin 7-Pin 14): Merupakan Data Bus 1-7

Anoda (Pin 15) : Merupakan masukan tegangan positif backlight

\section{Komunikasi Serial USART}

Dalam mikrokontroller Atmega 16 terdapat fitur USART (Universal Synchronous and Asynchronous serial Receiver and Transmitter ), merupakan salah satu mode komunikasi yang dimiliki oleh mikrokontroller Atmega 16. USART memiliki 2 pin (RxD dan TxD) untuk Asynchronous dan 3 bit TxD, RxD, xCK untuk Synchronous.

\section{Push Button}

Push button switch (saklar tombol tekan) adalah perangkat / saklar sederhana yang berfungsi untuk menghubungkan atau memutuskan aliran arus listrik dengan sistem kerja tekan unlock (tidak mengunci). Sistem kerja unlock disini berarti saklar akan bekerja sebagai device penghubung atau pemutus aliran arus listrik saat tombol ditekan, dan saat tombol tidak ditekan (dilepas), maka saklar akan kembali pada kondisi normal.

\section{Trafo Step Down}

Prinsip kerja suatu transformator adalah induksi bersama (mutual induction) antara dua rangkaian yang dihubungkan oleh fluks magnet. Dalam bentuk yang sederhana, transformator terdiri dari dua buah kumparan yang secara listrik terpisah tetapi secara magnet dihubungkan oleh suatu alur induksi. Kedua kumparan tersebut mempunyai mutual induction yang tinggi. Jika salah satu kumparan dihubungkan dengan sumber tegangan bolak-balik, fluks bolak-balik timbul di dalam inti besi yang dihubungkan dengan kumparan yang lain menyebabkan atau menimbulkan ggl (gaya gerak listrik) induksi ( sesuai 
dengan induksi elektromagnet) dari hukum faraday.

\section{Kapasitor}

Kapasitor Keramik adalah Kapasitor yang Isolatornya terbuat dari Keramik dan berbentuk bulat tipis ataupun persegi empat. Kapasitor Keramik tidak memiliki arah atau polaritas, jadi dapat dipasang bolak-balik dalam rangkaian Elektronika. Pada umumnya, Nilai Kapasitor Keramik berkisar antara $1 \mathrm{pf}$ sampai $0.01 \mu \mathrm{F}$. Kapasitor yang berbentuk Chip (Chip Capasitor) umumnya terbuat dari bahan Keramik yang dikemas sangat kecil untuk memenuhi kebutuhan peralatan Elektronik yang dirancang makin kecil dan dapat dipasang oleh Mesin Produksi SMT (Surface Mount Technology) yang berkecepatan tinggi.

\section{CodeVision AVR}

CodeVisionAVR pada dasarnya merupakan perangkat lunak pemrograman mikrokontroler keluarga AVR berbasis bahasa C. Ada tiga komponen penting yang telah diintegrasikan dalam perangkat lunak ini: Compiler C, IDE dan program generator. CodeVisionAVR dilengkapi dengan source code editor, compiler, linker dan dapat memanggil Atmel AVR studio dengan debuggernya.

Berdasarkan spesifikasi yang dikeluarkan oleh perusahaan pengembangnya, Compiler C yang digunakan hampir mengimplementasikan semua komponen standar yang ada pada bahasa C standar ANSI (seperti struktur program, jenis tipe data, jenis operator, dan library fungsi standar berikut penamaannya). Tetapi walaupun demikian, dibandingkan bahasa C untuk aplikasi komputer, compiler C untuk mikrokontroler ini memiliki sedikit perbedaan yang disesuaikan dengan arsitektur AVR tempat program C tersebut ditanamkan (embedded). Khusus untuk library fungsi, disamping library standar (seperti fungsi-fungsi matematik, manipulasi string, pengaksesan memori dan sebagainya).

\section{Resistor}

Resistor adalah komponen dasar elektronika yang selalu digunakan dalam setiap rangkaian elektronika karena bisa berfungsi sebagai pengatur atau untuk membatasi jumlah arus yang mengalir dalam suatu rangkaian. Dengan resistor, arus listrik dapat didistribusikan sesuai dengan kebutuhan. Sesuai dengan 
namanya resistor bersifat resistif dan umumnya terbuat dari bahan karbon. Satuan resistansi dari suatu resistor disebut Ohm atau dilambangkan dengan simbol $\Omega$ (Omega). Di dalam rangkaian elektronika, resistor dilambangkan dengan huruf "R". Dilihat dari bahannya, ada beberapa jenis resistor yang ada dipasaran antara lain : Resistor Carbon, Wirewound, dan Metalfilm. Ada juga Resistor yang dapat diubah-ubah nilai resistansinya antara lain : Potensiometer, Rheostat dan Trimmer (Trimpot). Selain itu ada juga Resistor yang nilai resistansinya berubah bila terkena cahaya namanya LDR (Light Dependent Resistor) dan resistor yang nilai resistansinya akan bertambah besar bila terkena suhu panas yang namanya PTC (Positive Thermal Coefficient) serta resistor yang nilai resistansinya akan bertambah kecil bila terkena suhu panas yang namanya NTC (Negative Thermal Coefficient.

\section{Kabel Enviromental (ENVA)}

Kabel enva merupakan kabel yang digunakan untuk membuat alarm ouput yang dihasilkan dari komponen yang diamankan. Penggunaan kabel enva ini sama seperti prinsip kerja limit switch yaitu hanya akan menghubung pada saat katupnya ditekan pada batas penekanan tertentu yang telah ditentukan dan akan memutus saat saat katup tidak ditekan.

\section{METODOLOGI PENELITIAN}

\section{Metode Penelitian}

Dalam penulisan tugas akhir ini metode yang digunakan dalam penelitian adalah :

1. Metode Perancangan Merupakan proses untuk membuat rancangan sistem yang digunakan sebagai objek penelitian yang dilakukan sampai pada hasil penelitian yang diharapkan.

2. Realisasi Perancangan

Merupakan proses untuk menjadikan suatu rencana menjadi perwujudan yang nyata.

3. Implementasi

Cara menerapkan perancangan.

4. Analisa

Analisa Perbandingan implementasi alat dengan perancangan alat, sehingga sesuai dengan kebutuhan sistem.

\section{Tempat Penelitian}

Penelitian dan Pengujian alat dilakukan di rangkaian PT.Putra Mulia Telekomunikasi Medan. 


\section{Peralatan Yang digunakan}

Untuk mendapatkan hasil perancangan yang optimal , maka sangat dibutuhkan peralatan berikut:

1. Multitester Digital 1 unit

2. Downloader Mikrokontroler 1 unit

3. Laptop 1 unit

4. Kabel jumper secukupnya

5. Converter USB to Serial 1 Unit

\section{HASIL DAN PEMBAHASAN}

Perancangan program keseluruhan merupakan perancangan program mulai dari proses pembacaan sensor aktif alarm pada BTS hingga pada proses koneksi antara mikorokontroler ATMega16 dengan modem GSM agar dapat melakukan proses kirim dan terima SMS dengan handphone tujuan.

Pengukuran dan implementasi ini meliputi, yaitu :

1) Pengukuran Rangkaian Sumber Tegangan DC 5V

2) Implementasi Tampilan LCD 16x2 Karakter.

3) Implementasi Kirim Dan Terima SMS Dengan Modem GSM.

4) Implememntasi Keseluruhan

\section{Pengukuran Rangkaian Sumber}

\section{Tegangan DC 5V}

Pengujian rangkaian sumber tegangan DC 5V dilakukan untuk mengetahui apakah rangkaian sumber tegangan DC 5V sudah dapat menghasilkan tegangan sebesar $5 \mathrm{~V}$ yang digunakan untuk mencatu sistem keseluruhan. Hasil pengujian keluaran rangkaian sumber tegangan DC $5 \mathrm{~V}$ ditunjukkan dalam Gambar 1

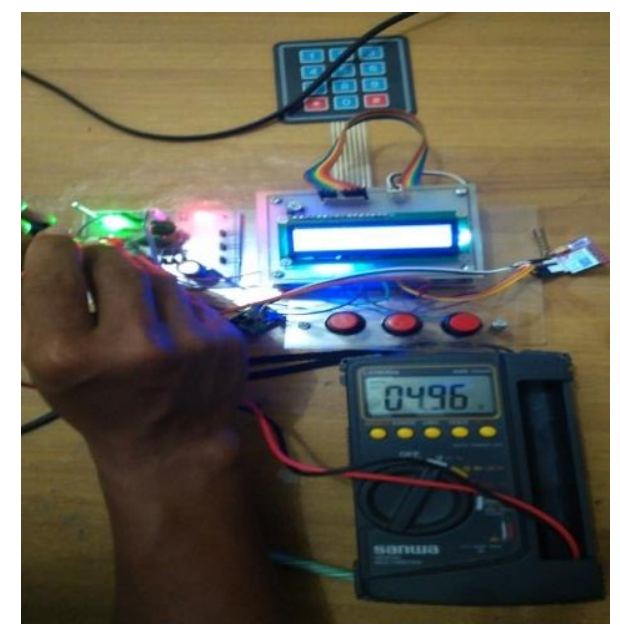

Gambar 1 Hasil Keluaran Rangkaian Tanpa Beban

\section{Implementasi LCD 16X2 Karakter}

Implementasi LCD 16X2 karakter bertujuan untuk mengetahui kesesuaian antara karakter-karakter yang dikirimkan oleh program di dalam mikrokontroler ATMega16 ke LCD dengan karakter yang tertampil pada layar LCD 16X2 karakter. Hasil 
pengujian LCD 16X2 karakter untuk meremote komputer dengan ditunjukkan dalam Gambar 2.

terhubungnya menggunakan port ssh atau sebagainya.

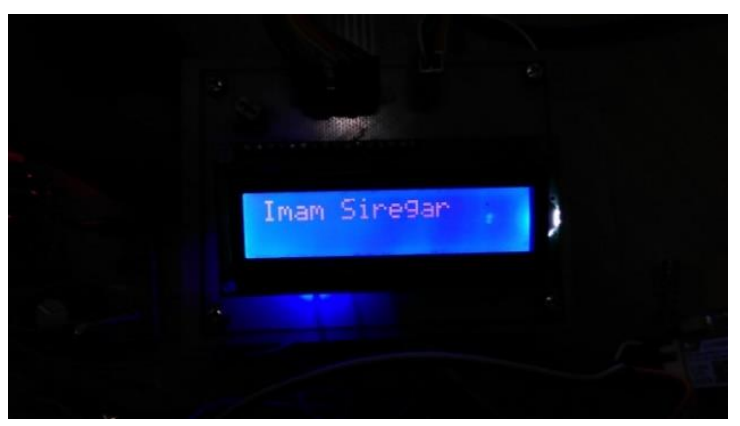

Hasil implementasi pengiriman SMS dari Module GSM SIM800L ditunjukan dalam gambar berikut ini

Gambar 2. Tampilan Hasil Rangkaian LCD 16x2

Hasil implementasi LCD 16x2 karakter menunjukkan bahwa string yang tertampil tiap baris LCD 16x2 karakter memiliki komposisi karakter yang identik dengan string yang dikirimkan mikrokontroller ATmega16 sehingga dapat disimpulkan bahwa LCD 16x2 karakter dapat berfungsi dengan baik.

\section{Implementasi kirim dan terima SMS menggunakan modem GSM}

Implementasi kirim dan terima SMS menggunakan modem GSM (General service for mobile) dilakukan untuk mengetahui apakah modem GSM dapat mengirim dan menerima SMS dengan baik. Pengujian kirim dan terima SMS disimuasikan dengan menggunakan Putty software.

Putty software adalah software remote console/terminal yang digunakan 


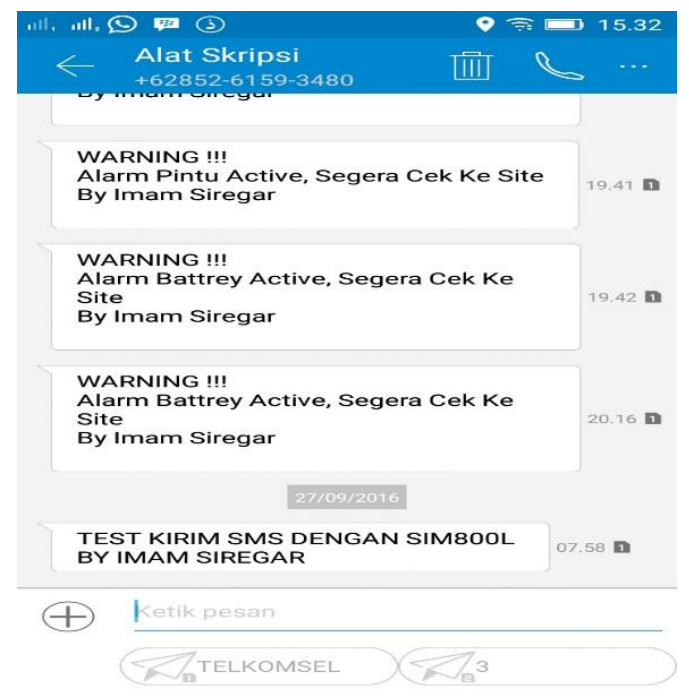

Gambar 5. Tampilan SMS Yang Diterima Handphone

Berdasarkan hasil implemnetasi kirim SMS menggunakan module GSM SIM 800L dapat diketahui bahwa module GSM sukses mengirimkan SMS kepada handphone dengan isi pesan yang saling berkesesuaian antara pesan yang dikirim oleh module GSM dengan pesan yang diterima perangkat handphone. Sedangkan hasil implementasi terima SMS menggunakan module GSM ditunjukkan dalam gambar berikut

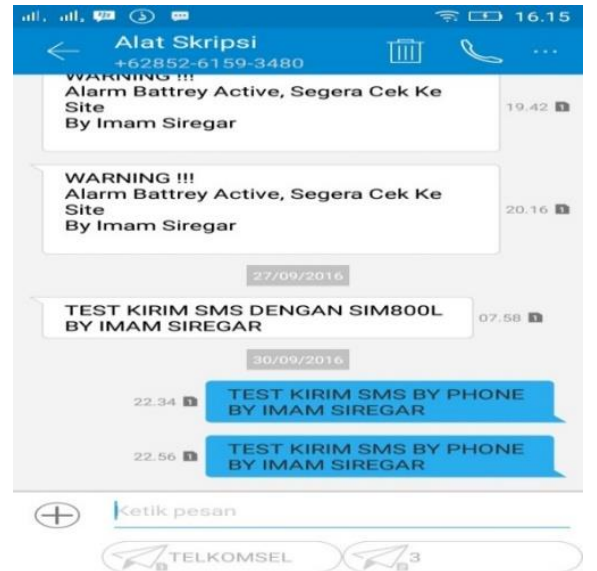

Gambar 6. Tampilan SMS Yang Dikirimkan Oleh Handphone Kepada Module GSM

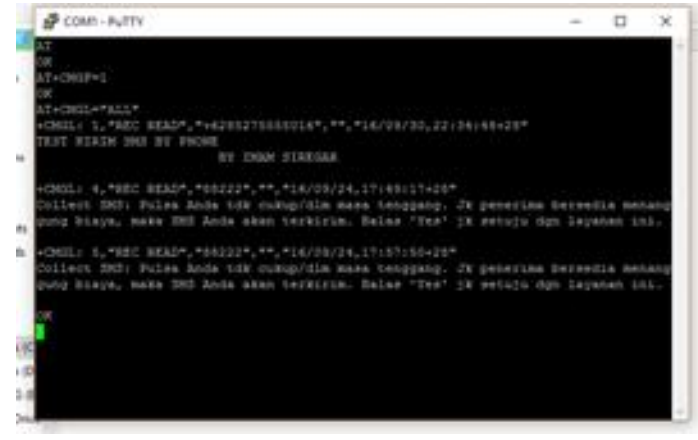

Gambar 7 Tampilan implementasi terima SMS pada software Putty

Hasil implementasi terima SMS menggunakan modem GSM suskses menerima SMS dari perangkat handphone dengan isi pesan SMS yang saling berkesesuaian antara pesan yang diterima oleh modem GSM dengan pesan yang dikirimoleh perangkat handphone.

\section{KESIMPULAN DAN SARAN}

\section{Kesimpulan}

Setelah melakukan perancangan alat dan pengujian serta menganalisa alat yang telah dibuat dapat disimpulkan seperti dibawah ini.

1) Sistem dapat melakukan peringatan keamanan kepada user ketika mendeteksi adanya indikasi pencurian melalui fasilitas SMS.

2) Mikrokontroler ATMega16 dapat melakukan program perangkat lunak yang telah dirancang untuk mengolah data dari sensor alarm aktif melalui push button yang telah dirancang terintegrasi dengan sitem. 
kemudian info alarm aktif melalui mikrokontroller ATmega16 akan diteruskan informasinya ke user melalui Module GSM SIM800L sehingga user mengetahui keadaan keamanan site tersebut

3) Alat yang dirancang telah berhasil berjalan sesuai fungsi sistem keamanan pada shelter BTS

\section{Saran}

Dalam proses pembuatan proyek Tugas Akhir ini tentu tidak lepas dari berbagai kesalahan, kekurangan maupun kelemahan, baik dari sistem peralatan yang dibuat maupun pelaksanaan pembuatan proyek tugas akhir ini. Untuk memperbaiki kekurangan dan kelemahan alat ini maka perlu dilakukan hal-hal sebagai berikut:

1. Alat yang telah dibuat dapat dimodifikasi agar dapat lebih mudah digunakan dalam penggunaanya. Tidak hanya internal alarm yang dapat di trigger, akan tetapi Eksternal alarm juga seperti peringatan kebakaran, kelembapan suhu shelter dan lain sebagainya.

2. Untuk pengembangan selanjutnya tidak hanya menggunakan media SMS sebagai komunikasinya tetapi bisa juga suatu saat menggunakan wireless smartphone.

\section{DAFTAR PUSTAKA}

Purnomo, Adi. 2007. AT Command. http://javaku.wordpress.com. Diakses tanggal 30ktober 2013.

Tim Prasimax Tanpa Tahun. AT-Command Untuk SMS.

Http:/www.mikron123.com)index.php)A plikasi- SMS/AT-Command- Untuk- SMS. Html. Diakses pada tanggal 20 Agustus . www.atmel.com diakses pada tanggal 15 juli 2016

Design. (2013, Agustus 20). SIMcom SIM800L_Hardware_Design_V1.00. Diakses $23 \quad$ Juli,2016,dari www.datasheetspdf.com/datasheet/SIM 800

Fahmizal. 2011. "Mengenal Bahasa Basic Pada Codevision AVR" Institut Teknologi Sepuluh November. Surabaya.

Smale, P.H. 1986. Sistem Telekomunikasi I: Edisi Kedua. Jakarta: Penerbit Erlangga.

Anggrianwan, A.R. 2014. Ancang Bangun Sistem Peringatan Keamanan Serta Pemantau Suhu Dan Kelembaban Shelter Bts Melalui Fasilitas Sms. Jurnal Teknik Elektro Universitas Brawijaya.

Ginting, H.D. 2013. Rancang Bangun Perangkat Pemantau Shelter Bts. Jurnal Teknik computer volume 2. Unikom Bandung.

Prasojo, K.S et all. Alat Monitoring Power Bts Menggunakan Sms Gateway Berbasis Mikrokontroller Atmega 8535.Jurnal Teknik Universitas Muhammadiyah Jember.

Lawriko, D.E et all. 2014 Sistem Deteksi Pengamanan Bts Menggunakan Infrared Dan Sms Gateway. Teknik Telekomunikasi Fakultas Ilmu Terapan Universitas Telkom

Marahadika, T.P. 2011. Perancangan Sistem Informasi Pengamanan Bts Berbasis Web. Teknik Telekomunikasi Fakultas Ilmu terapan Universitas Telkom

Aprilia, A.R et all. 2010. Simulasi Akses Data Base Bts ( Base Transceiver Station) Pada Jaringan Gsm Mengunakan Sms Gateway. Jurnal Fakultas Teknik Universitas Diponegoro. 